\title{
Influence of Irrigation Intervals under Different Sowing Dates on Water Relations, Yield and Quality Nutrition of Guar Forage Crop
}

\author{
Zizy M. Abbas, Nematallh Y.O. Mokhtar" and S.S.M Abo-Feteih" \\ Forge Crops Res. Dept., Field Crops Institute and "Soil, Water \& Environment \\ Research Institute, Agricultural Research Center, Cairo, Egypt.
}

\begin{abstract}
WO FIELD experiments were conducted at Giza Agriculture Research Station during the two growing seasons of 2015 and 2016. The investigation was carried out to study the effect of different irrigation intervals, i.e., two weeks and three weeks in combination with different sowing dates, i.e., $1^{\text {st }}$ April, $15^{\text {th }}$ April, $1^{\text {st }}$ May and $15^{\text {th }}$ May on Guar forage crop (Cyamopsis tetragonoloba L.,var. Shandaweel 1 ) crop - water relations, yield and yield components under middle Egypt conditions. The main results could be summarized as follows:-
\end{abstract}

The number of applied irrigations and seasonal water consumptive use (CU) were increased with decreasing irrigation interval days which the shortage irrigation interval (irrigation every 15 days) recorded the maximum CU under all sowing date with an overall average being 442 and $453 \mathrm{~mm}$ for first and second season, respectively. The same trend was found with sowing date, with plant sown in $1^{\text {st }}$ April consumed more water than the other sowing dates. The lowest water use efficiency (WUE) was recorded under longer irrigation interval (irrigation every 21days) comparable to (irrigation every 15 days) and values of WUE differed due to sowing date, which the S4 (sowing at $15^{\text {th }}$ May) gave the lowest WUE while, S1( sowing at $1^{\text {st }}$ April) obtained the highest value. The crop coefficient $(\mathrm{Kc})$ values started small and increased to reach their maximum values in mid season under all sowing dates, then decline again until the crop maturity under all sowing dates.

All yield and yield component traits were markedly affected by sowing date and irrigation interval. Most of the studied traits except leaves/stem ratio as well as fiber $\%$, decreased by delaying sowing date from $1^{\text {st }}$ April to $15^{\text {th }}$ May. Decreasing irrigation interval days from 21 to 15 days significantly increased plant height, number of branches/plant, fresh and dry yield ton $\mathrm{fad}^{-1}$, while leaves/stem ratio and crud fiber $\%$ which increased by increasing irrigation intervals from 15 to 21 days.

Keywords: Guar forage crop, Irrigation intervals, Water utilization efficiency, Plant and crop coefficient $(\mathrm{Kc})$.

\section{Introduction}

Guar or cluster bean ( Cyamopsis tetragonoloba, L.) is a drought tolerant annual legume grown principally in India and Pakistan. Also, guar is cultivated in small areas in USA, Australia and Africa. It can be eaten green like snap bean, feed to cattle or used as green manure (Gomaa et al., 2007). in Egypt, guar is a promising summer forage crop that could be used to reduce the gap between the available and required summer forage crops for livestock feeding especially in grass - legume mixtures to increase dry matter yield, protein percent and gave forage of better quality than pure crops (Farrag et al., 1997).
Water is considered an economical scare resource in many areas of the world especially in arid and semiarid regions as Arabic countries in especially in Egypt ; also, it is considered a limiting factor in agricultural expansion in all countries over the world. In Egypt, however, irrigation water is not sufficient for both irrigation and reclamation purposes due to limitation water resource coming from the stabilize share of the Nile water and the slight acquit of other renewable sources, which affects the sustainability of agricultural development and food security. The effective irrigation water management practices and maximization water productivity is the desired target in this situation. One of the most

\#Corresponding author e-mail: abofeteih66@gmail.com

DOI: 10.21608/agro.2017.1447.1072

C2017 National Information and Documentation Centre (NIDOC) 
important methods of water conservation are saving irrigation water by increasing irrigation intervals or decreasing irrigation depths. In this respect, Anton et al. (1995) stated that, the ecological importance of water is the result of its physiological importance. Every plant process is affected directly or indirectly by water supply Seyed et al. (2011). Noticed that the increases on irrigation intervals decrease forage yield in sorghum. Alian \& Mokhtar (2014) reported that the number of applied irrigations, seasonal water consumptive use and fresh yield of Jerusalem artichoke forging crop were increased with decreasing irrigation interval days .

Managing planting date influences crop growth and development as well as interaction between growth and development and stressful periods (Abd El Lattief, 2011). Selection of proper sowing date is vital to obtain high yield due to variation among the weather conditions (Murungu et al., 2010). The ability of guar to thrive under semi-arid conditions (Abidi et al., 2015) makes it highly suitable for the Egyptian condition. Planting date studies performed in areas with wide climate variation, such as $\mathrm{NW}$ India and Pakistan, Losavio et al. (2002) noticed higher guar seed yield in planting period of May to August. Similarly, mid-May planting of guar has been reported to produce the highest seed yield in Mediterranean environment of Italy (Gresta et al., 2013). Primarily, guar was used for fodder is grown from May to July under Egyptian condition. There are many climate changes in later years affects on growth crop yields. Additional to, no information is available on optimum planting date for guar in regions inside country. In view of these facts, the present work aimed to comparatively evaluating four planting dates under different irrigation intervals on yield and water use efficiency of guar forage crop under middle Egypt condition (Giza region) .

\section{Materials and Methods}

The present work was carried out at Giza Agricultural Research Station, Agricultural Research Center, Egypt in 2015 and 2016 summer growing seasons. The objectives of these experiments were aimed to study the effect of irrigation intervals (14 and 21 days) with four sowing dates, $1^{\text {st }}$ April, $15^{\text {th }}$ April , $1^{\text {st }}$ May and $15^{\text {th }}$ May on yield, yield components and some waterrelations of Guar forage crop grown in middle Egypt. The adopted treatments were arranged in a split plot design with three replicates. The main plots represented the irrigation intervals, while the sowing dates were set in the sub ones. The sub plot area equals $24 \mathrm{~m}^{2}$ (4x6 m).

The adopted experimental treatments assigned as followed:

1. Main plot (Irrigation intervals)

1.1. Two weeks (14 days $\mathrm{I}_{1}$ ).

1.2. Three weeks (21 days $\left.I_{2}\right)$.

1. Sub main plot (sowing dates )

2.1. 1 April $\left(\mathrm{S}_{1}\right)$.

2.2. 15 April $\left(\mathrm{S}_{2}\right)$.

2.3. 1 May $\left(\mathrm{S}_{3}\right)$.

2.4. 15 May $\left(\mathrm{S}_{4}\right)$.

During seed bed preparation, calcium superphosphate $\left(15.5 \% \mathrm{P}_{2} \mathrm{O}_{5}\right)$ was incorporated into topsoil a rate of $15.5 \mathrm{~kg} \mathrm{P}_{2} \mathrm{O}_{5}$ fad $^{-1}$. Furthermore, 24 $\mathrm{kg} \mathrm{KO} \mathrm{fad}^{-1}$ as potassium sulfate, $48 \% \mathrm{KO}_{2}$ added just before sowing. Nitrogen fertilizer was added in the form of ammonium sulfate, $20.5 \% \mathrm{~N}$ at the rate of $75 \mathrm{kgfad}^{-1}$ before the second irrigation. Irrigation was practiced as traditional furrow irrigation, and the crop was kept weed free by hand weeding at 21 and 33 DAS in the two seasons and no pests or diseases were observed in both seasons.

Weather data used in calculating potential water consumptive use were collected from Agrometeorological Giza Station (Latitude: 30 303 , Longitude: $31^{\circ}: 13^{-}$Elevation: 18.6 ) during the growing seasons and listed in Table 1. Particle size distribution according to Gee \& Bauder (1986) and the chemical analyses of soil, i.e., total $\mathrm{N}$ was determined according to Bremner \& Mulvaney (1982), available P(Olsen et al., 1954), total K (Hesse, 1972), EC (Richards, 1959) and pH (McLean, 1982). Field capacity was determined according to Cassel \& Nielsen (1986). Wilting point was determined according to Stakman \& Vanderhas (1962). Available water was calculated from the values of field capacity and wilting point. Bulk density was determined according to Blake \& Hartge (1986) were listed in Table 2 and Table 3.

Soil samples were taken from depths were 15$\mathrm{cm}$ successive layers down $60-\mathrm{cm}$ depth of the soil profile just before each growing season to determined soil moisture constants for the experiment site, and summarized as average in Table (2)

The Giza soil is a montmorillonitic, thermic, deep (Abdel - Wahed, 1983). Properties of the soil are shown in Tables 3 . 
TABLE 1. Some meteorological data at Giza Agriculture Research Station in 2015 and 2016 seasons

\begin{tabular}{lcccccccccc}
\hline Season & \multicolumn{3}{c}{$\mathbf{2 0 1 5}$} & \multicolumn{7}{c}{$\mathbf{2 0 1 6}$} \\
\hline Month & T max & T min & WS & RH & SR & T max & T min & WS & RH & SR \\
\hline April & 27.20 & 13.90 & 4.30 & 64.0 & 19.60 & 29.10 & 14.40 & 4.10 & 62.0 & 23.80 \\
May & 32.70 & 19.20 & 4.00 & 60.0 & 25.20 & 34.40 & 17.30 & 4.40 & 59.0 & 26.50 \\
June & 32.60 & 21.30 & 4.20 & 61.0 & 26.80 & 35.60 & 21.40 & 4.20 & 60.0 & 28.90 \\
July & 34.50 & 23.20 & 3.70 & 66.0 & 29.40 & 36.80 & 21.70 & 3.90 & 64.0 & 28.60 \\
August & 37.60 & 26.00 & 4.00 & 70.0 & 31.20 & 36.70 & 21.80 & 3.80 & 68.0 & 26.40 \\
September & 36.10 & 24.50 & 3.60 & 71.0 & 24.70 & 32.40 & 19.20 & 3.90 & 70.0 & 22.80 \\
October & 29.90 & 18.20 & 4.30 & 71.0 & 19.60 & 31.90 & 17.80 & 3.80 & 71.0 & 18.30 \\
Average & 32.94 & 20.90 & 4.01 & 64.0 & 25.21 & 33.84 & 19.09 & 4.01 & 64.0 & 25.04 \\
\hline
\end{tabular}

$\mathrm{T} \max$ and $\mathrm{T} \min =$ maximum and minimum temperatures, ${ }^{\circ} \mathrm{C} ; \mathrm{WS}=$ wind $\mathrm{speed} \mathrm{cm} / \mathrm{sec} ; \mathrm{RH}=$ relative humidity $\% ; \mathrm{SR}=$ solar ,radiation, $\mathrm{cal} / \mathrm{cm}^{2} / \mathrm{day}$

TABLE 2. Soil moisture constants (\% by weight) and bulk density $\left(\mathrm{g} \mathrm{cm}^{-3}\right)$ of soil site of Giza Agricultural Research Station.

\begin{tabular}{lcccc}
\hline Depth, cm & Field capacity & Wilting point & Available water & Bulk density \\
\hline $00-15$ & 41.9 & 18.6 & 23.24 & 1.15 \\
$15-30$ & 33.7 & 17.5 & 16.18 & 1.20 \\
$30-45$ & 28.4 & 16.9 & 11.46 & 1.22 \\
$45-60$ & 28.1 & 16.5 & 11.51 & 1.28 \\
\hline
\end{tabular}

TABLE 3. Some physical and chemical properties of the soil at the experimental stie.

Particle-size distribution

Soil fraction

Coarse sand

Fine sand

Silt

Clay

Textural class

Soil chemical analyses

Organic matter

Available N (KCl-extract)

Available P (Na-bicarbonate extract)

Available K (NH4 - a acetate extract)

$\mathrm{pH}$ (1:2.5, soil: water suspension)
Content \%

2.91

13.40

30.51

53.18

Clay

Content

$1.80 \%$

40. $0 \mathrm{mg} \mathrm{kg}^{-1}$

$19.0 \mathrm{mg} \mathrm{kg}^{-1}$

$304 \mathrm{mg} \mathrm{kg}^{-1}$

7.4 


\author{
Data recorded \\ Growth traits \\ 1. Plant height $(\mathrm{cm})$. \\ 2. Leaves /stem ratio. \\ 3. Number of branches plant ${ }^{-1}$. \\ 4. Fresh and dry yields (ton fad $^{-1}$ ) (faddan \\ $=0.42$ Hectar)
}

\section{Chemical composition}

The plant samples were collected from each sub plot, weighed and oven dried at $70^{\circ} \mathrm{C}$ for 48 $\mathrm{h}$ up to the constant weight, ground and prepared for digestion as described by Page et al .(1982). Chemical analysis of forage was done following the conventional methods recommended by the Association of the Official Agricultural Chemists (A.O.S.C. 1991) on the dried forage sample at $70^{\circ} \mathrm{C}$ of each cut to determine crude protein percentage (CP) \% and crude fiber percentage (CF) \%.

\section{Water relations}

Actual water consumptive use 'CU' (Actual evapotranspiration)

Water consumptive use was determined via soil samples from the sub plots just before each irrigation and $48 \mathrm{~h}$ later besides at harvest, in 15 $\mathrm{cm}$ segments along the $60 \mathrm{~cm}$ depth of the soil. The seasonal water use values were obtained from the sum of water consumptive use for all irrigations, from sowing until harvesting under different treatments. The CU was for etch irrigation was calculated according to Israelsen \& Hansen (1962) as follows:

$$
\mathrm{CU}=\left(\mathrm{Q}_{2}-\mathrm{Q}_{1}\right) \times \mathrm{ERZD} \times \mathrm{Bd}
$$

where: $\mathrm{CU}=$ Actual consumptive use ( $\mathrm{mm})$ $\mathrm{ERZD}=$ effective root zoon depth. $(\mathrm{mm})$

$\mathrm{Bd}=$ bulk density of soil $\left(\mathrm{g} \mathrm{cm}^{-3}\right)$

$\mathrm{Q}_{2}=$ the soil moisture two days after irrigation $(\% \mathrm{w} / \mathrm{w})$. $(\% \mathrm{w} / \mathrm{w})$.

$\mathrm{Q}_{1}=$ the soil moisture before next irrigation

\section{Water use efficiency (WUE)}

Water use efficiency (WUE) values were calculated in $\mathrm{kg}$ of Guar fresh yield produced per $\mathrm{m}^{3}$ of water consumed per faddan according to the following equation (Vites, 1965):

$$
\begin{aligned}
& \text { fresh yield }(\mathrm{kg} / \mathrm{fad}) \\
& \text { WUE. = ------------------ }
\end{aligned}
$$

Potential evapotranspiration determined by estimated ET formula

Reference evapotranspiration $\left(\mathrm{mmd}^{-1}\right)$ values were determined via the metrological data of Giza region illustrated in Table 1. Penman Monteith method was used to calculate ETp using CROPWAT 8 model (Smith, 1991) as follows:

$$
\mathrm{ETo}=\mathrm{ET} \operatorname{rad}+\mathrm{ET} \text { aero }
$$

where: $\mathrm{ETo}=$ Reference evapotranspiration of standard crop canopy $(\mathrm{mm} / \mathrm{d})$

ET $\mathrm{rad}=$ Radiation term $(\mathrm{mm} / \mathrm{d})$

ET aero $=$ Aerodynamic term $(\mathrm{mm} / \mathrm{d})$

$$
\mathrm{d}(\mathrm{Rn}-\mathrm{G}) 1 / \lambda
$$

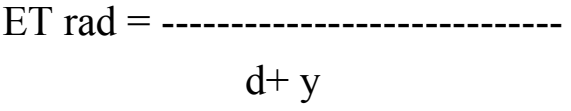

where: $\mathrm{ET} \mathrm{rad}=$ Radiation term $(\mathrm{mm} / \mathrm{d})$

$\mathrm{Rn}=$ Net radiation $\left(\mathrm{MJ} / \mathrm{m}^{2} / \mathrm{d}\right)$

$\mathrm{G}=$ Soil heat flux $\left(\mathrm{MJ} / \mathrm{m}^{2} / \mathrm{d}\right)$

$\lambda=$ Latent heat of evaporation $(\mathrm{MJ} / \mathrm{kg}$ )

$$
\text { ET aero }=\begin{array}{cc}
\mathrm{y} & 900 \\
-------- & -------\mathrm{U} 2(\text { ea - ed }) \\
\mathrm{d}+\mathrm{y}^{*} & (\mathrm{~T}+275)
\end{array}
$$

where : ETaero = Aerodynamic term of ETo $(\mathrm{mm} / \mathrm{d})$.

$\mathrm{y}=$ Psychrometric constant $\left(\mathrm{kpa} /{ }^{\circ} \mathrm{C}\right)$.

$\mathrm{U} 2=$ Wind speed $(\mathrm{m} / \mathrm{s})$.

ea-ed $=$ Vapour pressure deficit $(\mathrm{kpa})$.

$\mathrm{T}=$ Air temperature $\left({ }^{\circ} \mathrm{C}\right)$. $\left(\mathrm{kpa} /{ }^{\circ} \mathrm{C}\right)$

$\mathrm{y}^{*}=$ Modified psychrometric constant

\section{Crop coefficient (Kc crop)}

The Kc crop values were estimated from the general formula

$$
\mathrm{ET} \text { crop }=\mathrm{ET} 0 * \mathrm{Kc}
$$

where: ET crop = Crop evapotranspiration $(\mathrm{mm} /$ month). month).

ET0 $=$ Reference evapotranspiration $(\mathrm{mm} /$

$\mathrm{Kc}=$ Crop coefficient.

\section{Statistical analysis}

Data were statistically analyzed according to 
Snedecor \& Cochran (1980) and treatment means were compared by least significant difference test (LSD) at 0.05 level of significance. Bartlett's test was done to test the homogeneity of error variance. The test was not significant for all assessed traits, so, the two season's data were combined.

\section{Results and Discussion}

Growth traits

Data in Table 4 showed the effect of irrigation intervals, sowing dates and their interaction on growth traits namely; plant height, number of branches /plant and leaf/stem ratio.

\section{Effect of irrigation intervals}

Results indicated that irrigation intervals had significant effect on plant height, number of branches /plant and leaves/stem ratio. The means comparison of these traits indicated that increase of water deficit stress significantly decreased plant height and number of branches /plant. Also, increase of irrigation intervals from 15 to 21 days decreased these traits. In this concern, El-Ryad (2013) reported that increase water stress levels decreased plant height and number of shoots per plant of cowpea and sorghum forage crops, the same results found by Qasem et al. (2010) on cowpea. On the other hand, leaf/stem ratio trait significantly increased with increase of water deficit stress increase. Also, increase of irrigation intervals from 15 to 21 days increased the mean ratio of leaf to stem weight by $12 \%$ (Table 4). Seyed et al. (2011) stated that the effect of water deficit stress on leaf/stem ratio of sorghum was significant and with the increase in the intensity of drought stress increased, Also, Afsharmanesh (2009) on alfalfa fond the same result.

\section{Effect of sowing date}

There were significant differences for plant height among different sowing dates (Table 4). Early planting date $1^{\text {st }}$ April exhibited taller plants, increase in number of branches and leaf/stem ratio over all cuts, the mean values were 79.13, 6.16 and 1.28 , respectively.These results in harmony with the observations of Ramzan et al. (1992) who reported that plant height was generally reduced in delayed sowing in case of mungbean and in cowpea (Ichi et al., 2013). However $15^{\text {th }}$ April and $1^{\text {st }}$ May did not differ significantly in number of branches /plant and leaf/stem ratio. Later date $15^{\text {th }}$ May produced significant lowest values. This might be due to different climatic regimes with later date (Patel et al., 2002).

\section{Effect of interaction}

Interaction between irrigation intervals and sowing dates significantly influenced growth traits as shown in Table 4. Results indicated that the highest values of all studied growth traits were obtained from the treatment irrigation at15 days interval as interacted with $1^{\text {st }}$ April planting date except, leaves/stem ratio where the maximum value recorded with 21 days intervals interacted with $1^{\text {st }}$ April planting date.

\section{Fresh and dry yield \\ Effect of irrigation intervals}

Effect of different irrigation intervals on fresh and dry forage yield of guar and total cuts are shown in Table 5. The highest fresh and dry forage yield of all cuts were obtained when gaur plants irrigated at 15 days intervals treatment. Similar trend was observed in total fresh and dry yield, it increased by $25.64 \%$ and $33.74 \%$ for total fresh and dry yield, respectively. In this concern, El-Ryad (2013) revealed that the superiorities of cowpea and sorghum forage yield with $100 \%$ FC irrigation. Seyed et al. (2011) found that the maximum total fresh and dry yield were obtained with 5 days interval compared with 20 days interval in sorghum forage crop and Dadson et al. (2005) have also reported significant effects of water stress on cowpea.

\section{Effect of sowing date}

All sowing dates differed significantly on fresh and dry yields over all cuts and total yield (Table 5). Early sowing date $1^{\text {st }}$ April produced the highest values of 21.66 and 7.14 ton/fad for the total fresh and dry yield, respectively followed by second date $15^{\text {th }}$ April, while, sowing in $15^{\text {th }}$ May produced lower fresh and dry yield. These results are in harmony with those obtained by Gallagher \& Biscoe (1978), sowing at optimum time enables the crop to best use the available growth factors such as temperature and solar radiation at different stages of growth for high productivity. Akinola et al. (1979) found that early sowing gave higher dry matter yield in cowpea than late sowing, the same results observed by Ichi et al. (2013) on cowpea, Modawi et at. (1995) obtained higher forage production of cluster bean in early sowing.

\section{Interaction}

The effect of irrigation intervals and sowing dates interaction on fresh and dry yield were significant (Table 5). The highest values were pronounced by combination of irrigation intervals 15 days and $1^{\text {st }}$ April sowing date. 


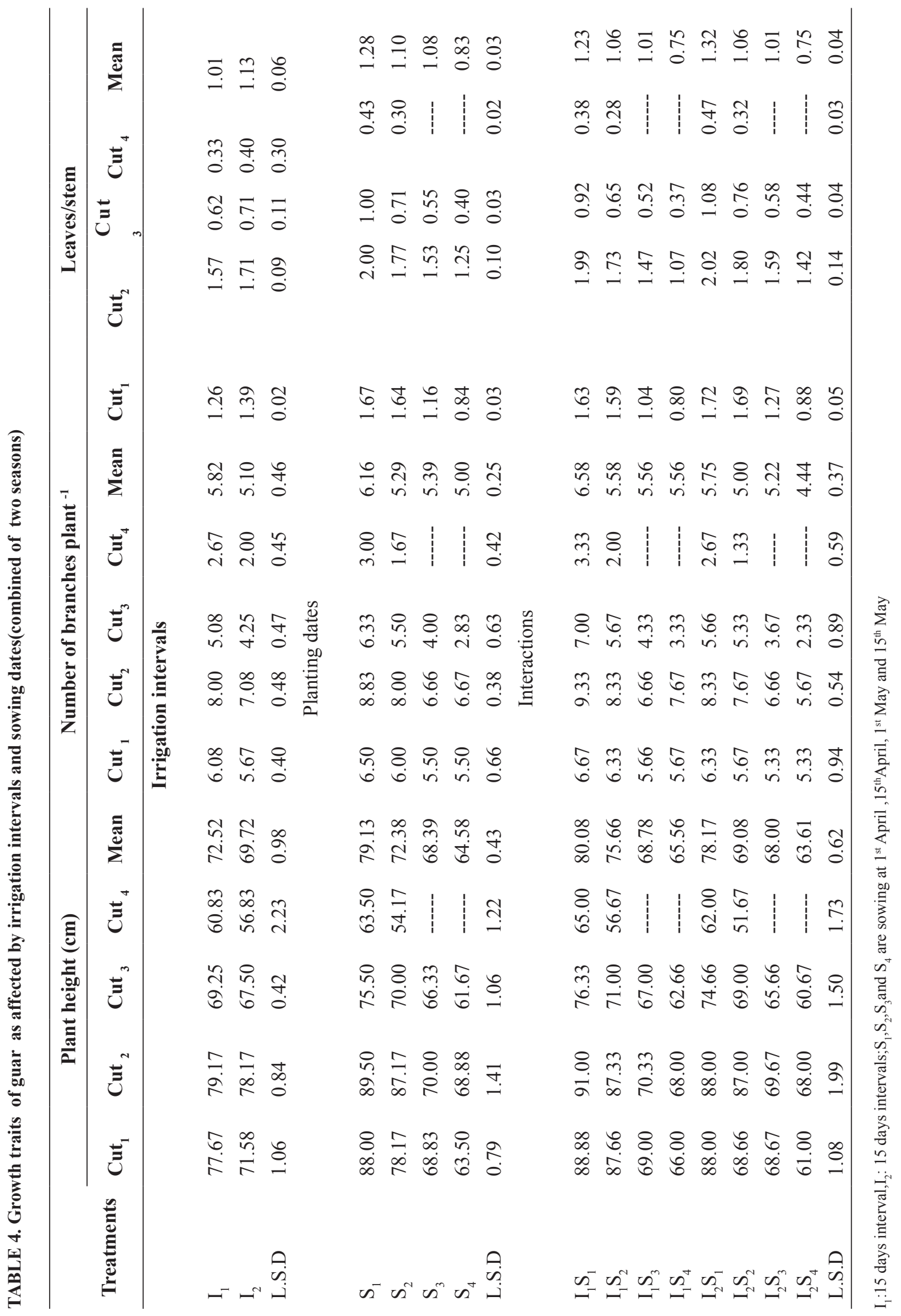

Egypt. J. Agron. 39, No. 3 (2017) 
TABLE 5. Effect of irrigation intervals and sowing dates on fresh and dry forage yield ton fad $^{-1}$ (combined of two seasons).

\begin{tabular}{|c|c|c|c|c|c|c|c|c|c|c|}
\hline \multirow[b]{2}{*}{ Treatments } & \multicolumn{5}{|c|}{ Fresh forage yield ton fad $^{-1}$} & \multicolumn{5}{|c|}{ Dry forage yield ton fad ${ }^{-1}$} \\
\hline & Cut 1 & Cut 2 & Cut 3 & Cut 4 & $\begin{array}{l}\text { Total } \\
\text { cuts }\end{array}$ & Cut 1 & $\begin{array}{c}\text { Cut } \\
2\end{array}$ & $\begin{array}{c}\text { Cut } \\
3\end{array}$ & $\begin{array}{c}\text { Cut } \\
4\end{array}$ & $\begin{array}{l}\text { Total } \\
\text { cuts }\end{array}$ \\
\hline \multicolumn{11}{|c|}{ Irrigation intervals } \\
\hline I1 & 5.70 & 6.79 & 4.34 & 3.16 & 19.99 & 1.26 & 1.56 & 0.90 & 0.60 & 4.32 \\
\hline $\mathrm{I} 2$ & 4.55 & 5.55 & 3.29 & 2.46 & 15.91 & 0.95 & 1.24 & 0.62 & 0.39 & 3.23 \\
\hline L.S.D & 0.12 & 0.15 & 0.37 & 0.38 & 0.51 & 0.03 & 0.04 & 0.08 & 0.09 & 0.12 \\
\hline \multicolumn{11}{|l|}{ Planting dates } \\
\hline S1 & 6.01 & 7.57 & 4.92 & 3.13 & 21.66 & 2.14 & 2.50 & 1.90 & 0.55 & 7.14 \\
\hline $\mathrm{S} 2$ & 5.68 & 6.97 & 4.22 & 2.49 & 19.39 & 2.05 & 2.35 & 1.73 & 0.40 & 6.55 \\
\hline S3 & 4.99 & 5.66 & 3.66 & ---- & 14.31 & 1.89 & 2.05 & 1.60 & ---- & 5.54 \\
\hline S4 & 3.83 & 4.49 & 2.45 & ---- & 10.77 & 1.62 & 1.77 & 1.32 & ---- & 4.71 \\
\hline L.S.D & 0.21 & 0.32 & 0.21 & 0.12 & 0.49 & 0.05 & 0.07 & 0.05 & 0.03 & 0.11 \\
\hline \multicolumn{11}{|l|}{ Interactions } \\
\hline I1S1 & 6.55 & 8.44 & 5.32 & 3.46 & 23.77 & 1.26 & 1.70 & 0.99 & 0.61 & 4.56 \\
\hline I1S2 & 6.31 & 7.84 & 4.82 & 2.86 & 21.83 & 1.19 & 1.54 & 0.87 & 0.50 & 4.10 \\
\hline I1S3 & 5.98 & 5.98 & 4.31 & ---- & 16.23 & 1.11 & 1.12 & 0.75 & ----- & 2.98 \\
\hline I1S4 & 3.97 & 4.90 & 2.89 & ---- & 11.76 & 0.65 & 0.86 & 0.42 & ----- & 1.93 \\
\hline $\mathrm{I} 2 \mathrm{~S} 1$ & 5.46 & 6.70 & 4.52 & 2.80 & 19.54 & 1.02 & 1.31 & 0.81 & ---- & 3.14 \\
\hline $\mathrm{I} 2 \mathrm{~S} 2$ & 5.05 & 6.10 & 3.61 & 2.12 & 16.94 & 0.91 & 1.15 & 0.59 & 0.49 & 3.17 \\
\hline $\mathrm{I} 2 \mathrm{~S} 3$ & 4.00 & 5.34 & 3.01 & ---- & 12.35 & 0.67 & 0.97 & 0.45 & 0.29 & 2.41 \\
\hline I2S4 & 3.69 & 4.08 & 2.02 & ---- & 9.79 & 0.59 & 0.68 & 0.23 & ---- & 1.50 \\
\hline L.S.D & 0.29 & 0.45 & 0.29 & 0.17 & 0.69 & 0.07 & 0.10 & 0.07 & 0.04 & 0.15 \\
\hline
\end{tabular}

$\mathrm{I}_{1}: 15$ days interval, $\mathrm{I}_{2}: 15$ days intervals; $\mathrm{S}_{1}, \mathrm{~S}_{2}, \mathrm{~S}_{3}$ and $\mathrm{S}_{4}$ are sowing at $1^{\text {st }}$ April, $15^{\text {th }}$ April, $1^{\text {st }}$ May and $15^{\text {th }}$ May

\section{Chemical composition}

Effect of irrigation intervals

The analysis of variance showed that irrigation intervals had significant effect on protein and crud fiber percentage of guar forage yield (Table 6). The protein percentage decrease with the increase of irrigation intervals from 15 to 21 days over cuts, where it decreased from 15.65 to $15.45 \%$ of the mean protein percentage. The results of this research is accordance with reports of Nielsen et al. (2006) on corn, millet and triticale and Seyed et al. (2011) on sorghum who explain this result by the sensitivity of cellular growth to water efficiency, the decreasing of water potential in meristem is a cause for reduction of the turgor (potential) pressure, that isn't enough for the cell growth ; this subject is one of the causes of decreasing protein synthesis. On the other hand, there are significant increase in crude fiber percentage with increase irrigation intervals from 15 to 21 days .
Effect of sowing date:

All sowing dates differed significantly in protein percentage (Table 6). Sowing guar early at $1^{\text {st }}$ April produced higher protein $\%$ than late sowing $15^{\text {th }}$ May among all cuts. These results could be attributed to decrease in dry matter yield. On the other hand, early sowing date decreased crud fiber

\section{Effect of interaction}

The interaction of irrigation intervals and sowing dates revealed that mean of protein percentage over cuts reached to its maximum value (16.19\%) under irrigation at 15 days intervals as interacted with $1^{\text {st }}$ April, whereas the maximum mean value was $26.97 \%$ of crude fiber under irrigation at 21 days intervals and $15^{\text {th }}$ May planting date (Table 6). 
TABLE 6. Crude protein $\%$ and crude fiber \% of pearl millet as affected by water intervals and planting date (first season).

\begin{tabular}{|c|c|c|c|c|c|c|c|c|c|c|}
\hline \multirow[b]{2}{*}{ Treatments } & \multicolumn{5}{|c|}{ Protein (\%) } & \multicolumn{5}{|c|}{ Crude fiber \% } \\
\hline & Cut 1 & Cut 2 & Cut 3 & Cut 4 & Mean & Cut 1 & $\begin{array}{c}\text { Cut } \\
2\end{array}$ & $\begin{array}{c}\text { Cut } \\
3\end{array}$ & Cut 4 & Mean \\
\hline \multicolumn{11}{|c|}{ Irrigation intervals } \\
\hline I1 & 16.04 & 16.57 & 15.46 & 14.52 & 15.65 & 25.58 & 26.79 & 27.34 & 28.00 & 26.78 \\
\hline $\mathrm{I} 2$ & 15.76 & 16.31 & 15.27 & 14.46 & 15.45 & 25.59 & 26.81 & 27.53 & 28.12 & 26.86 \\
\hline L.S.D & 0.26 & 0.02 & 0.11 & 0.03 & 0.09 & 0.01 & 0.23 & 0.06 & 0.07 & 0.01 \\
\hline \multicolumn{11}{|c|}{ Planting dates } \\
\hline S1 & 16.61 & 17.13 & 16.11 & 14.88 & 16.18 & 25.30 & 26.49 & 27.06 & 27.86 & 26.68 \\
\hline S2 & 16.06 & 16.59 & 15.40 & 14.09 & 15.53 & 25.37 & 26.58 & 27.26 & 28.25 & 26.87 \\
\hline S3 & 15.78 & 16.28 & 15.28 & ------ & 15.78 & 25.81 & 27.02 & 27.61 & ----- & 26.82 \\
\hline S4 & 15.16 & 15.75 & 14.67 & ------ & 15.19 & 25.87 & 27.11 & 27.81 & ----- & 26.93 \\
\hline L.S.D & 0.24 & 0.03 & 0.06 & 0.03 & 0.06 & 0.02 & 0.02 & 0.05 & 0.03 & 0.02 \\
\hline \multicolumn{11}{|c|}{ Interactions } \\
\hline I1S1 & 16.62 & 17.12 & 16.14 & 14.88 & 16.19 & 25.29 & 26.47 & 26.99 & 27.78 & 26.64 \\
\hline I1S2 & 16.26 & 16.86 & 15.55 & 14.17 & 15.71 & 25.36 & 26.58 & 27.15 & 28.21 & 26.83 \\
\hline I1S3 & 16.79 & 16.24 & 15.36 & ------ & 15.81 & 25.79 & 26.99 & 27.53 & ------ & 26.77 \\
\hline I1S4 & 15.49 & 16.05 & 14.79 & ------ & 15.45 & 25.86 & 27.11 & 27.69 & ------ & 26.89 \\
\hline $\mathrm{I} 2 \mathrm{~S} 1$ & 16.59 & 17.13 & 16.08 & 14.89 & 16.17 & 25.31 & 26.52 & 27.13 & 27.95 & 26.72 \\
\hline I2S 2 & 15.85 & 16.32 & 15.25 & 14.02 & 15.36 & 25.37 & 26.58 & 27.37 & 28.29 & 26.91 \\
\hline $\mathrm{I} 2 \mathrm{~S} 3$ & 15.77 & 16.32 & 15.21 & ------ & 15.77 & 25.81 & 27.05 & 27.70 & ------ & 26.85 \\
\hline $\mathrm{I} 2 \mathrm{~S} 4$ & 14.82 & 15.46 & 14.54 & ------ & 14.94 & 25.88 & 27.11 & 27.92 & ------ & 26.97 \\
\hline L.S.D & 0.34 & 0.04 & 0.08 & 0.04 & 0.08 & 0.02 & 0.02 & 0.08 & 0.04 & 0.02 \\
\hline
\end{tabular}

$\mathrm{I}_{1}: 15$ days interval, $\mathrm{I}_{2}: 15$ days intervals; $\mathrm{S}_{1}, \mathrm{~S}_{2}, \mathrm{~S}_{3}$ and $\mathrm{S}_{4}$ are sowing at $1^{\text {st }}$ April, $15^{\text {th }}$ April, $1^{\text {st }}$ May and $15^{\text {th }}$ May, respectively.

\section{Water relations}

Actual water consumptive use (Actual evapotranspiratio )

Results in Table 4 show that, the overall averages of actual water consumptive use (Eta) in 2015 and 2016 seasons were 1716.2 and 1760.1 $\mathrm{cm}^{3}$, respectively.

It's clear that seasonal water consumptive use (ETa ) was increased as intervals days value decreased since the ETa value under the 15 days interval was increase by $15.18 \%$ more than those under 21 days interval treatments, in the first season. Similar trend was observed in the second season with increased reached to $14.91 \%$. Two seasons results reveal that, regardless of sowing date, water consumptive use was increased as intervals days decreased. These results may be attributed to increased number of irrigations and the soil moisture was more available for extraction by plant roots and as well as soil surface evaporation under short time irrigation. On other hand, results also showed that, slight increased was found in $2^{\text {nd }}$ growing season compared to the $1^{\text {st }}$ season especially under short time irrigation. This could be attributed to higher temperature prevailed in the $2^{\text {nd }}$ growing season (Table1). These results are in the harmony with those obtained by El- Sabbagh et al. (2002) who noticed that seasonal water use was increased with decreasing irrigation interval days. Other similar results are obtained by Moussa \& AbdelMaksoud (2004). Recently El-Sarag (2013) reported that increasing irrigation intervals from 10 up to 
15 and 20 decrease CU for wheat crop in North Egypt (AL Arish region ) .

With respect to sowing date (Table 7), results indicate that maximum seasonal $\mathrm{CU}$ values were $1774.9 \mathrm{~m}^{3}$ was recorded for early sowing date $\mathrm{S}_{1}$ (sowing on $1^{\text {st }}$ April) as compared with other both sowing date; $\mathrm{S}_{2}, \mathrm{~S}_{3}$ and $\mathrm{S}_{4}$, respectively with an increased arranged between $+0.97,3.39$ and 8.891 $\%$ more than $\mathrm{S}_{2} \mathrm{~S}_{3}$ and $\mathrm{S}_{4}$ sowing date in the first season. However in second season, similar trained was found with maximum CU value being 1839.6 $\mathrm{m}^{3}$ for $\mathrm{S}_{1}$ treatment, with an increases reach to
$1.48,5.40$ and $10.41 \%$ for the same respective sowing date treatments. Maximum values of $\mathrm{CU}$ were rustles from interaction between $\mathrm{S}_{1} \mathrm{x} \mathrm{I}_{1}$ with values being 1904.3 and $1984.8 \mathrm{~m}^{3}$ for season first and second, respectively. These results indicate that ETa values increased with early sowing date, whereas delaying sowing date gradually decrease $\mathrm{CU}$ values. This may be due to shortage growing season under delayed sowing date caused in minimize develop roots growth as well as decrease water uptake by plant. These results are in a good agreement with those obtained by Hussien et al. ( 1990).

TABLE 7. Seasonal water consumptive use $\left(\mathrm{m}^{3}\right)$ of guar (Cyamopsis tetragonoloba $\left.\mathrm{L}.\right)$ as affected by irrigation regime and sowing date at Giza region in 2015 and 2016 seasons.

\begin{tabular}{lcccccc}
\hline Season & \multicolumn{3}{c}{ Summer 2015 } & \multicolumn{3}{c}{ Summer 2016 } \\
\hline Irrigation Treatment & I1 & I2 & Average & I1 & I2 & Average \\
\hline $\mathrm{S}_{1}$ & 1904.3 & 1645.5 & 1774.9 & 1984.8 & 1694.4 & 1839.6 \\
$\mathrm{~S}_{2}$ & 1875.3 & 1640.8 & 1758.1 & 1961.9 & 1663.0 & 1812.5 \\
$\mathrm{~S} 3$ & 1860.8 & 1568.5 & 1714.7 & 1854.9 & 1625.6 & 1740.3 \\
$\mathrm{~S}_{4}$ & 1788.2 & 1446.1 & 1617.2 & 1805.9 & 1490.2 & 1648.1 \\
Average & 1857.2 & 1575.2 & 1716.2 & 1901.9 & 1618.3 & 1760.1 \\
\hline
\end{tabular}

$\mathrm{S}_{1}, \mathrm{~S}_{2}, \mathrm{~S}_{3}$ and $\mathrm{S}_{4}$ sowing on $1^{\text {st }}$ April, $15^{\text {th }}$ April , $1^{\text {st }}$ May and $15^{\text {th }}$ May , respectively . $\mathrm{I}_{1}$ and $\mathrm{I}_{2}$; Irrigation interval every 14 and 21 days.

Water Use Efficiency (WUE)

Values of water use efficiency as recorded in Table 8 , indicate that irrigation at 14 days interval gave the maximum water use efficiency of 9.91 and $9.67 \mathrm{~kg}$ fresh yield $/ \mathrm{m}^{3}$ water in first and second season, respectively. While the minimum value was 9.30 and $9.06 \mathrm{~kg}$ fresh yield $/ \mathrm{m}^{3}$ water was recorded for long irrigation time (21 days interval) for the same respective treatments. The two-season results indicate that, there was sight increased with decreasing number of irrigation according to irrigating at short days interval. These results are in harmony with those reported by El-Marsafay (2000) and in accordance with observation of Krogman et al (1980) who found that faba bean water use efficiency was similar among different irrigation treatments since the seed and straw yield linearly depended on total water received.
Results in Table 8 indicate the highest value of water use efficiency 12.20 and $11.77 \mathrm{~kg}$ fresh yield $/ \mathrm{m}^{3} /$ fad was obtained with sowing plant at $1^{\text {st }}$ April $\left(\mathrm{S}_{1}\right)$ for both growing seasons. However the lowest one 6.66 and $6.54-\mathrm{kg}$ fresh yield $/ \mathrm{m}^{3} /$ fad) were obtained with sowing plant at $15^{\text {th }}$ May $\left(\mathrm{S}_{4}\right)$. Both season results reveal that delaying sowing date to mid of May decreased WUE to a minimum value compared to other sowing dates. It could be stated that delaying sowing date for the almost a month could reduce the guar fresh yield as a result of highly temperatures affect on crop growth at develop stage in this sowing date time, in additional to shortening of growing season duration if associated with the appropriate evapotranspiration (Eta) due to higher temperatures at delayed sowing date, will be decreased water use efficiency of guar. 
TABLE 8. Water use efficiency ( $\mathrm{kg}$ fresh yield $/ \mathrm{m}^{3} /$ fed) of guar (Cyamopsis tetragonoloba $\mathrm{L}$.) as affected by irrigation regime and sowing date at Giza region in 2015 and 2016 seasons.

\begin{tabular}{lcccccc}
\hline Season & \multicolumn{3}{c}{ Summer 2015 } & \multicolumn{3}{c}{ Summer 2016 } \\
\hline Irrigation Treatment & $\mathbf{I}_{\mathbf{1}}$ & $\mathbf{I}_{\mathbf{2}}$ & Average & $\mathbf{I}_{\mathbf{1}}$ & $\mathbf{I}_{\mathbf{2}}$ & Average \\
\hline $\mathrm{S}_{1}$ & 12.48 & 11.87 & 12.20 & 11.98 & 11.53 & 11.77 \\
$\mathrm{~S}_{2}$ & 11.64 & 10.32 & 11.03 & 11.13 & 10.19 & 10.70 \\
$\mathrm{~S}_{3}$ & 8.72 & 7.87 & 8.33 & 8.75 & 7.60 & 8.21 \\
$\mathrm{~S}_{4}$ & 6.58 & 6.77 & 6.66 & 6.51 & 6.57 & 6.54 \\
Average & 9.91 & 9.30 & 9.63 & 9.67 & 9.06 & 9.39 \\
\hline
\end{tabular}

$\mathrm{S}_{1}, \mathrm{~S}_{2}, \mathrm{~S}_{3}$ and $\mathrm{S}_{4}=$ sowing on $1^{\text {st }}$ April, $15^{\text {th }}$ April, $1^{\text {st }}$ May and $15^{\text {th }}$ May. $\mathrm{I}_{1}$ and $\mathrm{I}_{2}$; Irrigation interval every 14 and 21 days, respectively

Potential evapotranspiration ETp

Potential evapotranspiration (ETo) throughout guar crop (Cyamopsis tetragonoloba L) growing season duration was estimated from the climatic data of Giza research station (Table 1) according to Penman Monteih formula included in CropWat 8 program. Crop coefficient (Kc) under experimental condition were calculated as follows:

\section{$\mathrm{Kc}=\mathrm{Eta} / \mathrm{ETo}$}

Generally, results shown in Table 9 indicated that there were small differences between calculated ETo for the two seasons. This may be due to the variation in the weather conditions. In first season estimated ETc values were 776.7, $742.5,839.6$ and $833.1 \mathrm{~mm}$ for $\mathrm{S}_{1}, \mathrm{~S}_{2}, \mathrm{~S}_{3}, \mathrm{~S}_{4}$, respectively. However, the highest values for crop coefficient $(\mathrm{Kc})$ for April May, June, July and August were 0.33, 0.49, .67, 1.02, 0.51 and
0.23 respectively, were obtained for early sowing date ( $1^{\text {st }}$ April $)$ which the lowest values being $0.31,0.47,0.73,0.55$ and 0.27 results from delayed sowing date( $15^{\text {th }}$ May). Results in Table 9 also, indicate that $\mathrm{Kc}$ values started small according to the small plants cover in the early stage, then increased to reach their maximum values in mid season as a result of a complete crop canopy with highest value of ETo, and then tended to decline again until the crop maturity. These results are true for all sowing date treatments. In this concaern, Doorenbos et al. (1986) reported that for most crops Kc values increase from a low value at time of crop emergence to maximum value during the period when it reaches full development and decline as the crop matures. Recently, Abbas et al. (2008) reported that Kc values varied with growth stages for guar plant growth at Wad Medani-Sudan with values were $0.44,1.03$ and 0.63 for $\mathrm{Kc}$ in $\mathrm{Kc}$ mid and $\mathrm{Kc}$ end, respectively.

TABLE 9. op coefficient $(\mathrm{Kc})$ and ETo ( $\mathrm{mm} / \mathrm{month})$ estimated by some ET formulas for Guoar crop at Giza region in 2015 and 2016 seasons.

\begin{tabular}{|c|c|c|c|c|c|c|c|c|c|c|c|c|}
\hline & \multicolumn{3}{|c|}{ S1 } & \multicolumn{3}{|c|}{ S2 } & \multicolumn{3}{|c|}{ S3 } & \multicolumn{3}{|c|}{ S4 } \\
\hline & Kc & Eto & Eta & $\mathrm{Kc}$ & Eto & Eta & Ke & Eto & Eta & $\mathrm{Ke}$ & Eto & Eta \\
\hline April & 0.31 & 152.4 & 47.3 & 0.22 & 76.2 & 16.7 & & & & & & \\
\hline May & 0.49 & 198.7 & 96.8 & 0.48 & 198.7 & 95.1 & 0.21 & 198.7 & 42.1 & 0.31 & 96.2 & 30.3 \\
\hline June & 1.02 & 193.5 & 198.2 & 1.00 & 193.5 & 194.3 & 0.56 & 193.5 & 107.5 & 0.47 & 193.5 & 91.6 \\
\hline July & 0.51 & 211.1 & 106.9 & 0.55 & 211.1 & 115.4 & 0.83 & 211.1 & 175.2 & 0.73 & 211.1 & 154.3 \\
\hline August & 0.23 & 18 & 4.2 & 0.23 & 108.4 & 24.5 & 0.53 & 217 & 115.3 & 0.55 & 217 & 118.6 \\
\hline September & & & & & & & 0.30 & 19.2 & 5.7 & 0.27 & 115.4 & 30.8 \\
\hline $\begin{array}{l}\text { Se a s on a l } \\
\text { Etc }\end{array}$ & 0.58 & 773.7 & 453.4 & 0.54 & 787.9 & 446 & 0.52 & 839.5 & 445.8 & 0.49 & 833.2 & 425.6 \\
\hline
\end{tabular}

$\mathrm{ET} 0=$ Potential evapotranspiration, Eta $=$ actual crop evapotranspiration, $\mathrm{Kc}:=$ Crop coefficient 


\section{Conclusion}

Achieving higher water utilization efficiency became the most important challenge for scientists in the agriculture, particularly in arid and semi arid areas. Mitigation such problem could be achieved by irrigation intervals. Furthermore, determined the optimum sowing date to give the highest yield under the variation among the weather conditions to improve growth and yield of Guar forage crop. Our results showed that sowing at $1^{\text {st }}$ April in combination with irrigation every 15 days improved growth characteristics and final yield at Giza region.

\section{References}

Abbas, I.M.I., Adam, H. and Adeeb, A.M. (2008) Measuring Crop Coefficient $(\mathrm{Kc})$ of Guar (Cyamopsis tetragonoloba (L.) Taub) under Gezira, Sudan Condition. "Competition for Resources in a Changing World: New Drive for Rural Development", Tropentag, October 7-9, 2008, Hohenheim

Abd El Lattief, E.A. (2011) Growth and fodder yield of forage pearl millet in newly cultivated land as affected by date of planting and integrated use of mineral and organic fertilizers. Asian Jounal of Crop Scinece, 3 (1), 35-42.

Abdel Wahed, A. (1983) Research report on soil survey. Soil Survey EMCIP Res. Extension Centers. Publication No.62 Consortium for International Development. ARC, Cairo May 1983.

Abidi, N., Liyanage, S., Auld, D., Imel, R.K., Norman, L., Grover, K., Angadi, S., Singla, S. and Trostle, C. (2015) Challenges and opportunities for increasing guar production in the United States to support unconventional oil and gas production. In: "Hydraulic Fracturing Impacts and Technologies", Uddameri, V., et al. (Ed.), pp. 207-226. CRC Press, Boca Raton. http://dx.doi.org/10.1201/b18581-13.

Akinola, J.A. and Davies, J.H. (1979) Effect of sowing date on forage and seed production on 14 varieties of cowpea (Vigna unguiculata (L.) walps). Samaru Bulletin, 295 -304.

Alian, Fatma S. and Mokhtar, Nemait Allah Y. O. (2014) Effect of different irrigation intervals and cutting times of plant top on water use efficiency, productivity and quality of Jerusalem artichoke plants. J. Biological, Chemical and Environmental Sci. 9( 1), $652-623$.

Anton, N.A., Abbas, F.A., Yousef, K.M.R. and El-Hyatemy, Y. (1995) Effect of irrigation intervals and potassium fertilization on fodder beet plant under calcareous soil conditions. Egypt J. Appl.Sci. 10 (12), 404-423.
AOSA (1991) Association of Official Seed Analysits. Rules for testing seed. J. Seed Technology, 12 (3), $1-25$.

Bermner, J.M. and Mulvaney, C.S. (1982) "Total Nitrogen", pp. 595-624. Amer. Soc. Agron., Madison, Wisconsin, USA.

Blake, G.R. and Hartge, K.H. (1986) Bulk Density. In: "Methods of Soil Analysis. Part 1 - Physical and Mineralogical Methods", A. Klute (Ed.), $2^{\text {nd }}$ ed. American Society of Agronomy, Madison WI

Cassel, D.K. and Nielsen, D.R. (1986) Field capacity and available water capacity. In: "Methods of Soil Analysis Part 2: Chemical and Microbiological Properties" Page, A.L., Miller, R.H. and Keeney, D.R. (Ed.), $2^{\text {nd }}$ ed. Agronomy Society of America, Madison, WI.

Dadson, R.B., Hashem, F.M., Javaid, I., Joshi, J., Allen, A.L. and Devine, T.E. (2005) Effect of water stress on the yield of cowpea (Vigna unguiculata L.Walp.) Genotypes in the delmarva region of the united states. J. Agronomy Crop Sci.191, 210-217.

Doorenbos, J., Kassam, A.H., Bentvelsen, C.L.M., Branscheid, V., Plusje, J.M.G.A., Vittenbognard, G.O. and Van Derwal, H.K. (1986) Yield response to water. Irrigation and drainage paper No. 33, FAO. Rome, Italy

El- Sabbagh, A.A., Abd El- Hafez, S.A., El-Bably, A.Z. and Abou-Ahmed, E.I. (2002) Response of wheat crop to irrigation intervals and foliar application of potassium. J . Agric. Res. Tanta Univ. 28 (2), 525538.

El-Marsafay, S.M. (2000) Scheduling irrigation of wheat crop under different phosphorus fertilizer application times in Middle Egypt. Proc. $5^{\text {th }}$ Conference-Meteorology \& Sustainable Development, pp. 182-195.

El-Sarag, Eman I. (2013) Cowpea- sorghum mixtures as affected by water stress levels and forage mixing ratio in semi - arid regons. World J. Agric.Sci. 9(4), 325-334.

El-Ryad, Eman I. (2013) Cowpea- sorghum mixtures as affected by water stress levels and forage mixing ratio in semi - arid regons. World J. Agric.Sci. 9 (4), 325-334.

Farrag, A.A. and Abd El-Latee, E.M.F (1997) Effect of NPK combination on growth and yield of guar (Cyamopsis tetragonoloba (L.) taub). Al-Azhar J. Agric. Res. 23, 15-25.

Gallagher, J.N. and Biscoe, P.V. (1978) A physiological 
analysis of cereal yield.II Partitioning of dry matter. Agricultural Progress, 53, 51-70.

Gee, G.W. and Bauder, J.W. (1986) Particle size analysis. In:"Methods of Soil Analysis Part 2: Chemical and Microbiological Properties", Page, A.L., Miller, R.H. and Keeney, D.R. (Ed.), $2^{\text {nd }}$ ed. Agronomy Society of America, Madison, WI.

Gomaa, A.M. and Mohamed, M.H. (2007) Application of bio-organic agriculture and its effect on guar (Cyamopsis tetragonoloba L.) root nodules, forage, seed yield and yield quality. Worled J. Agric. Sci. 3 (1), 91-96.

Gresta, F., Sortino, O., Santonoceto, C., Issi, L., Formantici, C. and Galante, Y. (2013) Effects of sowing times on seed yield, protein and galactomannans content of four varieties of guar (Cyamopsis tetragonoloba L.) in a Mediterranean Environment. Industrial Crops and Products, 41, 46-52. http://dx. doi.org/ 10.1016/ j.indcrop. 2012.04 .007

Hesse, P.R. (1972) "A Textbook of Soil Chemical Analysis". Chem. Pub. Co. Inc., New York.

Husain, M.M., Reid, J.B., Othman, H. and Gallagther (1990) Growth and water use of faba beans (Vicia faba) in subhumid climate. Root and shoot adaptations to drought stress. Field Crops Rresearch, 23(1), 1-17.

Ichi, J.O., Igbadun, H.E., Miko, S. and Samndi, A.M. (2013) Growth and yield response of selected cowpea (Vigna unguiculata (L.) walp) Varieties to irrigation interval and sowing date. The Pacific Journal of Science and Technology, (14), 1.453-463.

Israelsen, O.W. and Hansen, V.E. (1962) "Irrigation Principles and Practices" $.3^{\text {rd }}$ ed., John Wiley and Sons Inc., New York, USA.

Krogman, K.K., Mc Kenzie, R.C. and Hobbs, E.H. (1980) Response of faba bean yield, protein production and water use to irrigation. Canadian Journal of Plant Science, 60, 91-96.

Losavio, N., Ventrella, D. and Vonella, A.V. (2002) Environmental adaptability and productive potential of the guar grown in irrigation system in southern Italy. Agronomy Journal, 36, 171-175.

McLean, E.O. (1982) Soil $\mathrm{pH}$ and lime requirement. In: "Methods of Soil Analysis, Part 2: Chemical and Microbiological Properties" AL Page (Ed). $2^{\text {nd }}$ ed. pp. 199-224, Agronomy \#9. American Society of Agronomy Inc, and Soil Science Society of America Inc. Madison, Wisconsin, USA.

Modawi, R.S., Abdelwahab, S. and Ibrahim, Y.M.
(1995) Productivity of six forage legumes at different sowing dates in the United Arab Emirates University. Legume-Research, 18 (2), 117-120.

Moussa, A.M. and Abdel-Maksoud, H.H. (2004) Effect of soil moisture regime on yield and its components and water use efficiency for some wheat cultivars. Annals Agric. Sci., Ain Shams Univ. 49(2), 515-530.

Murungu, F.S. and Madanzi, T. (2010) Seed priming, genotype and sowing date effects on emergence, growth and yield in a tropical low altitude area of Zimbabwe. Afr. J. Agric. Res. 5 (17), 2341- 2349.

Nielsen, D.C., Vigil, M.F. and Benjamin, J.G. (2006) Forage yield response to water use for dry land corn, millet and triticale in the central Great Plains. Agron.J. 98, 992-998.

Olsen, S.R, Cole, O.V., Watanabe, F.S. and Dean, A.L. (1954) Estimation of available phosphorus in soil by extraction with sodium bicarbonate. U.S.D.A. Circ., 939.

Page, A.L., Miller, R.H. and Keeney, D.R. (1982) "Methods of Soil Analysis" Part 2. Amer. Soc. Agron., Madison, Wisconsin, USA

Patel, M.S., Pathak, A.R. and Patel, K.M. (2002) Correlated response in culsterbean (Cyamopsis tetragonoloba L.Taub). Prog. Agri. 2 (2), 198-190.

Qasem, J.R. and Biftu, K.N. (2010) Growth analysis and responses of cowpea (Vigna sinensis L. Savi Ex Hassk) and redroot pigweed (Amaranthus retroflexus L.) grown in pure and mixed stands to density and water stresses. The Open Horticulture Journal, 3, 21-30.

Ramzan, C.M., Nadeem, M.A. Khan, R.H. and Khan, M.A. (1992) Effect of sowing date on mungbean seed yield under rainfed conditions. Pak. J. Agric. Res. 30 (2), 205-211.

Richards, L.A. (Ed) (1959) "Diagnsis and Improvement Saline and Alkali Soils" U.S. Dept. Agric. Hand Book.

Seyed, G.R., Seghatoleslami, M.J., Javadi, H. and Elham, A. (2011) Effect of irrigation intervals and planting patterns on yield and qualitative traits of forage sorghum. Adances in Environmental Biology, 5(10), 3363-3368.

Smith, M. (1991) A computer program for irrigation planning and management. FAO irrigation and drainage Paper No: 56. FAO Roma.

Snedecor, G.W. and Cochran, W.G. (1980) "Statistical Methods". $7^{\text {th }}$ ed., Iowa State Univ. Press., Ames, IA., USA. 
Stakman, W.P. and Vanderhas, G.G. (1962) The use of the pressure membrane apparatus to determine soil moisture constants at pF3.0 to 4.2 inclusive. Institute for land and water management research, Note No. 139.
Vites, F.G. Jr. (1965) Increasing water use efficiency by soil management. In: "Plant Environment and Efficient Water Use". W.H Pierro, D.k.r Khom, J. Pesek and R.Show (Ed.), pp. 259274. Am. Soc. Agron., Madison, Wisc.

(Received 6/8/2017; acecpted 23 / $10 / 2017$ )

\section{تأثير فترات الري ومواعيد الزراعة على إنتاجية وجودة محصول علف الجوار \\ "زيزي مصطفى عباس، نعمة الله يوسف عثمان مختار *و صلاح سالم محمد ابوفتيح

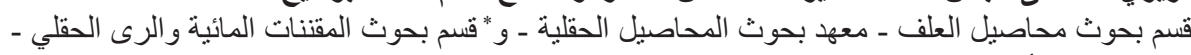 معهد بحوث الأر اضى و المياه و البيئة ـ مركز البحوث الزفئ الزر اعية ـ القاهره ـمصر.}

أجريت تجربتان حقليتان بمحطة مركز البحوث الزر اعية بالجيزة خلال موسمي 2015 و 2016 لدر اسة تأثير

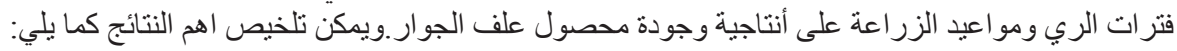
ـ أشارت النتائج إلى ان تأثثير كلا من فترات الري ومواعيد الزر اعة أثرت معنويا على صفات النمو ،و الانتاجية وجودة المحصول.

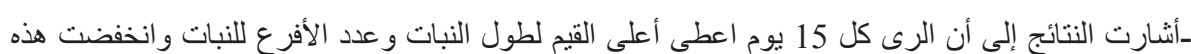

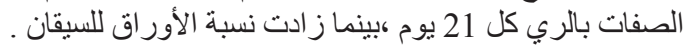

ـ أدى الرى كل 15 يوم إلي أعلي القيم للوزن الغض و الوزن الجاف للفدان لحاصل علف الجوار لكل حشه

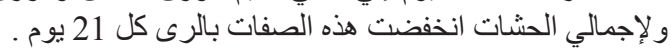

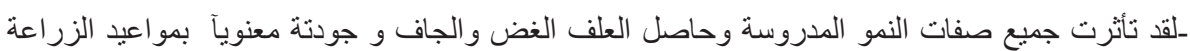

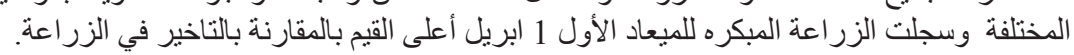

ـاوضحت النتائج أن التفاعل بين معاملات الرى ومواعيد الزر اعة اثرت معنوياً على صفات النمو وحاصل

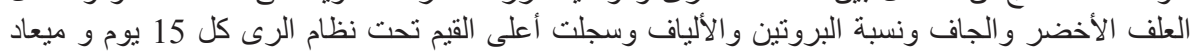

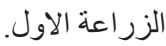

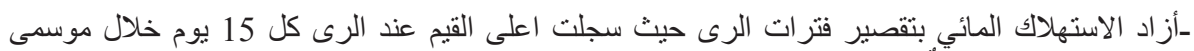

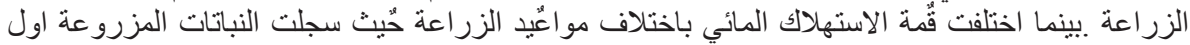
ابريل أعلى قيم للاستهلاك المائي.

ـافضل قُيمة لإنتاجية وحدة المياه كانت عند زر اعة محصول الجوار في اول أبريل بينما انخفضت قُّبمة انتاجُية

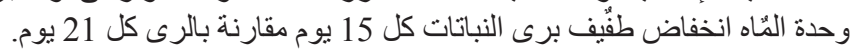

-بدا معامل المحصول ضئيلا في بداية موسم النمو ثم ازداد تدريجيا حيث بلغ أقصاه في (شهر يونيه ويوليو ) ثم انخفض بعد ذللك بتقام النبات في العمر.

ـاعلى قيم الاستهلاك النظرى ومعامل المحصول سجلت عند زر اعة المحصول مبكرا (15-1 ابريل ) . 